\title{
Effects of a commercial, suspended eastern oyster nursery upon nutrient and sediment chemistry in a temperate, coastal embayment
}

\author{
Shannon L. Meseck ${ }^{1, *}$, Yaqin Li ${ }^{1}$, Mark S. Dixon ${ }^{1}$, Karen Rivara ${ }^{2}$, Gary H. Wikfors ${ }^{1}$, \\ George Luther III $^{3}$
}

\author{
${ }^{1}$ NOAA/NMFS, 212 Rogers Avenue, Milford, Connecticut 06418, USA \\ ${ }^{2}$ Aeros Cultured Oyster Company, 10273 N Bayview Road, Southold, New York 11971, USA \\ ${ }^{3}$ University of Delaware, College of Marine Studies, 700 Pilottown Road, Lewes, Delaware 19958, USA
}

\begin{abstract}
We explored chemical effects of a commercial Floating-Upwelling-System (FLUPSY) stocked with juvenile oysters Crassostrea virginica in a small embayment. Water from the FLUPSY outflow was analyzed for nutrients (total ammonia, nitrate+nitrite, phosphate, and silicate), total suspended material (TSM), chlorophyll (chl) $a$, and particulate organic carbon and nitrogen (C:N). The output from the FLUPSY was compared to estuarine transects in the Bay to determine if any outputs from the FLUPSY could be detected within the embayment. Sediment samples taken near the FLUPSY and throughout the embayment were analyzed for fluxes of total ammonia, hydrogen sulfide, and oxygen. Dissolved nutrient concentrations in the FLUPSY output were no higher than in the rest of the embayment. There were, however, elevated concentrations of TSM and chl $a$ near the FLUPSY compared to other sites in the embayment. Furthermore, suspended organic matter near the FLUPSY had a C:N ratio near the Redfield ratio, while the rest of the embayment had an elevated C:N ratio indicative of phytoplankton nitrogen limitation. These findings suggest that nutrient recycling by microbes may have been occurring in the vicinity of the FLUPSY. Sediment data showed no difference in fluxes of oxygen, hydrogen sulfide, or total ammonia between the FLUPSY output and elsewhere in the embayment. These findings suggest that the FLUPSY had very minimal effects on the chemical ecology of the embayment.
\end{abstract}

KEY WORDS: Aquaculture $\cdot$ Sediments $\cdot$ Nutrients $\cdot$ Phytoplankton $\cdot$ Oysters

Resale or republication not permitted without written consent of the publisher

\section{INTRODUCTION}

With growing demands for food from the sea, annual aquaculture production has risen from less than 1 million tons in 1950 to 52.5 million tons in 2008 (excluding aquatic vegetation), with an average annual growth rate of $8.3 \%$ (FAO 2010). In 2008, worldwide aquaculture production was estimated to have a US dollar value of $\$ 98.4$ billion (FAO 2010), with the Asia-Pacific region accounting for $89 \%$ of production in quantity and $79 \%$ in terms of value. Bivalve aquaculture represented only $25 \%$ of world aquaculture production in 2008, with oysters ac- counting for $31.8 \%$ of the production, followed by $24.6 \%$ from carpet shells and clams, $12.4 \%$ from mussels, and $10.7 \%$ from scallops (FAO 2010). Recently, the US Commission on Ocean Policy and the National Oceanic and Atmospheric Administration recognized the importance of aquaculture in the United States, which has been slowly rising at an annual rate of $2 \%$ (see www.nmfs.noaa.gov/ aquaculture/docs/policy/doc_aquaculture_policy_ 2011.pdf). Success hinges on establishment and implementation of sustainable industry mariculture practices with a consistent regulatory regime built upon a scientific foundation. 
Bivalve aquaculture can influence an ecosystem by 3 primary interactions: (1) food consumption and waste production, (2) organisms and the structures they are in (i.e. bags, cages, long-lines), and (3) harvesting and bed maintenance (Dumbauld et al. 2009). Additions to the environment from bivalve aquaculture, however, are minimal compared to aquaculture operations for other animals (i.e. finfish and crustaceans), with just the addition of the shellfish themselves and the infrastructure to grow them on. Unlike pelleted feeds used in finfish aquaculture, bivalve food is supplied by the environment, with waste being returned to the environment as dissolved nutrients and semi-solid biodeposits. Therefore, there is no eutrophication caused by the addition of nutrients (Rodhouse \& Roden 1987). The energy requirement for the rearing of mussels is only $10 \mathrm{kcal}$ of fossil energy input per kcal of protein output, which is the same as for sheep farming and rangeland beef (Folke \& Kautsky 1992). Despite similar energy balances as in commonly accepted agriculture practices, concerns remain that the environmental effects of bivalve aquaculture are not fully understood. Natural populations of bivalves are known to control phytoplankton blooms, reduce total suspended solids through filter feeding (Cloern 1982, Officer et al. 1982, Haamer 1996, Soto \& Mena 1999), and recycle and remove nutrients from the water column (Doering \& Oviatt 1986, Rice 1999, Wikfors 2011). Environmental models constructed by Meeuwig et al. (1998) for 6 embayments on Prince Edward Island, Canada, estimated that mussel farming reduced phytoplankton biomass by 45 to $85 \%$. These calculations suggest that intense bivalve culturing can alter material and energy cycles in some coastal systems, leading to concerns that bivalves could overgraze a system for other consumers (i.e. zooplankton, fish). Bivalve grazing, however, may reduce the effects of eutrophication by sequestering nutrients assimilated by the bivalves and also stimulate primary production by: (1) increasing light penetration by reducing turbidity (assuming that phytoplankton are light-limited, not nutrient-limited), (2) increasing new growth of algae by removal of existing cells, (3) shifting the phytoplankton community to fastergrowing species, (4) increasing nutrient cycling, and (5) increasing nutrient availability in an embayment (Prins et al. 1995, Newell 2004).

In an embayment, a number of factors can influence the distribution and speciation of a chemical. For example, dissolved total ammonia concentrations in an embayment can be influenced by sediment exchange, riverine input, biological utilization, point sources along the embayment, and coastal exchange. Most research on bivalve mariculture has been focused on how the production and sedimentation of feces and pseudofeces affects the benthic and pelagic communities (reviews by Cranford et al. 2008, 2009, McKindsey et al. 2011, Shumway 2011). A few studies have examined the potential effects on nutrient cycling, fluxes and retention at the coastal ecosystem scale (Newell 2004, Nizzoli et al. 2006, 2011, Cranford et al. 2007). Most of these studies have been before-after-control-impact (BACI) studies, but there are a few problems with a BACI design: (1) the response variable that is being measured varies naturally over time, therefore any changes observed over time may not be related to the before and after impact but rather to natural environmental changes; (2) there will always be natural differences between the control and the impact site (i.e. sediment grain size, tides, water depth, water chemistry); and (3) when just the immediate area of an aquaculture installation is studied, the effects it has on the temporal variability of the larger ecosystem cannot be assessed.

To determine if outputs from a nursery-culture system growing Crassostrea virginica oyster seed could be detected within the magnitude of temporal variability in the environment, a commercial nursery site employing a Floating-Upwelling-System (FLUPSY; Rivara et al. 2002) in East Creek (South Jamesport, New York, USA; Fig. 1) was studied. In this study, a BACI approach would not be appropriate for the following reasons: (1) there is large temporal variability in the embayment (e.g. phytoplankton, nutrients, zooplankton); (2) oysters are only put into the system when the water temperature will support growth and are removed once they reach $25 \mathrm{~mm}$; therefore, the load to the system changes weekly; and (3) this embayment is affected by many other seasonal human activities (boating, fishing, dredging). However, because the FLUPSY takes water from the embayment (input) and has a known discharge pipe, we can use the fixed-station, estuarine-transect approach commonly used in estuaries to determine anthropogenic point and non-point sources in a watershed (Cutter \& San Diego-McGlone 1990, Maie et al. 2006, Wu et al. 2012). This approach involves a 2-step process: (1) quantification of the inputs (nutrients, total suspended material [TSM], chlorophyll [chl] a) from the freshwater endmember (salt marsh), saltwater endmember (Great Peconic Bay), sediments within the embayment, and the FLUPSY; and (2) sampling a fixed-station, estuarine transect during different time periods throughout the season when the FLUPSY is 


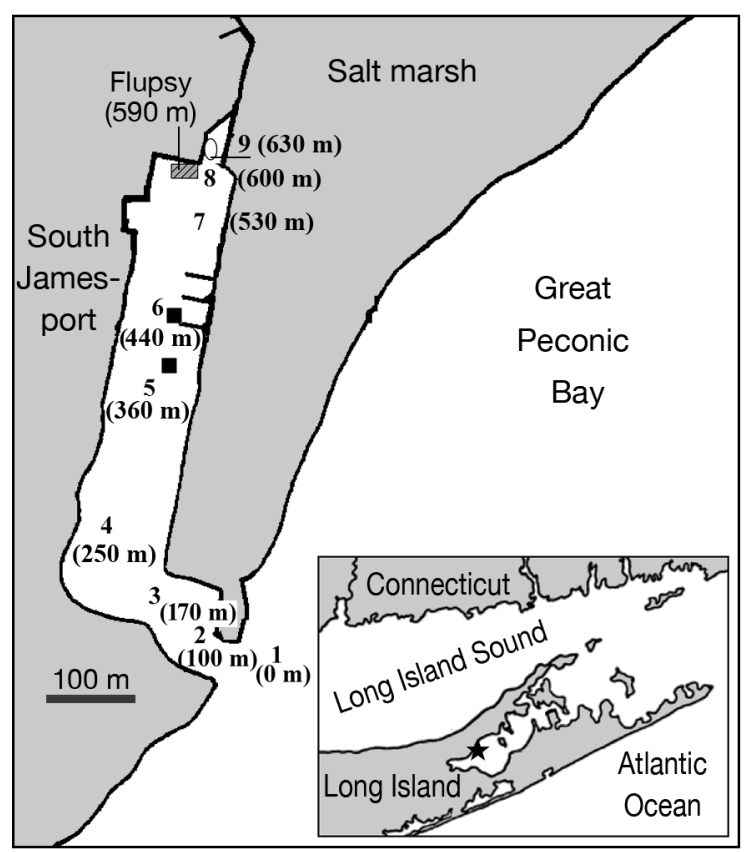

Fig. 1. The East Creek embayment in South Jamesport ( $\star$ ), New York, USA, containing the Aeros Cultured Oyster Company FLUPSY. Water samples were collected monthly from June to November 2010 at sites (1 to 9) along an estuarine transect. Sediment samples were collected at 3 locations (salt marsh: 6 sites [oval]; mid-estuary: 2 sites each [squares]; FLUPSY: 15 sites taken around the perimeter $[<1 \mathrm{~m}$ apart from each other]), also from June to October 2010

utilized. The approach is commonly used in estuaries to determine anthropogenic point and non-point sources in a watershed.

We conducted a comprehensive study of the East Creek oyster nursery effects on the water and sediment chemistry in East Creek. This study quantified the: (1) water column nutrient concentrations, (2) surface water chl a concentrations, and (3) sediment characteristics for the entire embayment and around the commercial nursery. By comparing the embayment's seasonal variability to the output of the commercial nursery, we assessed if impacts from the oyster nursery upon the embayment can be detected within the natural temporal and spatial variability of the embayment.

\section{MATERIALS AND METHODS}

\section{Site description}

East Creek is a man-made tidal basin in the former location of a natural salt marsh in South Jamesport, New York, USA (Fig. 1). It is maintained by the Town of Riverhead, in the Hamlet of Jamesport, as a pub- lic-access location with a boat launch, recreational fishing facilities, and a seasonal marina. East Creek is bound on the north end by a salt marsh (freshwater endmember) and on the southern end by the Great Peconic Bay (saltwater endmember). There are no other point source inputs into this embayment, so any other loading into the embayment would be through non-point sources (e.g. runoff). The channel and mouth of East Creek are dredged on an annual basis. East Creek has an average depth of $3 \mathrm{~m}$ (mean high water), is $105 \mathrm{~m}$ wide and $640 \mathrm{~m}$ long from Great Peconic Bay to the salt marsh, giving a total volume of $2.02 \times 10^{8} 1$. The average tidal range is $1 \mathrm{~m}$. The FLUPSY $\left(40^{\circ} 56^{\prime} 38.60^{\prime \prime} \mathrm{N}, 72^{\circ} 34^{\prime} 13.86^{\prime \prime} \mathrm{W}\right)$ was located in the northern end of East Creek adjacent to the salt marsh (Fig. 1).

\section{FLUPSY}

FLUPSYs are relatively recent innovations, but are already common and important components of shellfish aquaculture operations in North America (Rivara et al. 2002). A FLUPSY is an in situ nursery system designed to increase efficiency of water flow, and therefore microalgal food delivery, to post-set shellfish. The system is typically incorporated into a floating dock and deployed in a productive coastal waterway. The FLUPSY is designed to move water laterally through shellfish seed, rather than lifting water to a land-based upweller (Rivara et al. 2002).

The present study was conducted at a commercial FLUPSY oyster nursery operated between about May and October by Aeros Cultured Oyster Company. The FLUPSY has 4 sections that are capable of running independently. Each of the 4 sections consists of a central trough, 10 upwellers (50 drums [ 19 1] with a mesh-lined bottom and open top) plumbed to the central trough, and a propeller-driven motor $(1 \mathrm{hp})$ that draws water through the system. Bottom water is drawn into the FLUPSY at a rate of $1.32 \times 10^{5} \mathrm{l} \mathrm{h}^{-1}$ (i.e. it would take $63.6 \mathrm{~d}$ to pump all the water in the embayment through the FLUPSY) and exits through a pipe at the surface. Post-set, juvenile eastern oysters Crassostrea virginica (3 to $5 \mathrm{~mm}$ shell height) were deployed in the FLUPSY at an average stocking density of $<21$ dry oysters per drum.

\section{Sampling}

Water quality and sediment characteristics were measured at 9 stations in East Creek between the 
mouth (Stn 1, representing seawater endmember inputs, Great Peconic Bay input, $0 \mathrm{~m}$ ) and the upstream salt marsh (Stn 9, representing freshwater endmember inputs, $630 \mathrm{~m}$; Fig. 1). The first station was in Peconic Bay at $40^{\circ} 56^{\prime} 34^{\prime \prime} \mathrm{N}$ by $72^{\circ} 34^{\prime} 22^{\prime \prime}$ W. At each station, surface water samples $(0.25 \mathrm{~m}$ below the surface) and bottom-water samples $(0.25 \mathrm{~m}$ above the sediment surface) were taken between June and November 2010 with a Go-Flo bottle for nutrients (total ammonia, nitrate+nitrite, phosphate, and silica), salinity, temperature, TSM, chl $a$, and organic carbon:nitrogen ratio (C:N). Samples were taken during periods of different tidal cycles (i.e. flood, ebb).

The same variables were analysed in samples taken at the inflow and outflow pipe of the FLUPSY during the estuarine transect sampling, as well as in additional samples throughout the months of June to November (taken at only the input and output pipes of the FLUPSY, but not at the estuarine transect stations). Based upon the difference between the inflow and the outflow pipes, removal/inputs attributable to the FLUPSY were calculated.

Salinity (accuracy \pm 0.1 and precision \pm 0.01 ) and temperature (accuracy $\pm 0.15^{\circ} \mathrm{C}$ and precision $\pm 0.10^{\circ} \mathrm{C}$ ) data were collected with a hand-held YSI ${ }^{\circledR}$ 36-100. Nutrient samples were taken by filtering $120 \mathrm{ml}$ water on pre-combusted $\left(450^{\circ} \mathrm{C}\right.$ overnight), $25 \mathrm{~mm}$ GF/F filters placed in low-pressure syringe filter holders. The syringes were rinsed 3 times with sample water before being filled with $120 \mathrm{ml}$ of water. The syringe filter holder was then placed on the bottom of the syringe and the water was pushed through into a $125 \mathrm{ml}$ HDPE bottle cleaned previously with $10 \%$ hydrochloric acid. Water samples were stored in a cooler with ice until analysis at the lab. The GF/F filter was removed from the syringe filter holder and folded into combusted aluminum foil for organic C:N analysis. At the lab, filters were stored frozen at $-20^{\circ} \mathrm{C}$ until analysis.

TSM samples were collected on pre-weighed, $47 \mathrm{~mm}$ GF/F filters. Depending upon the water characteristics, 100 to $250 \mathrm{ml}$ of water were filtered. The filters were rinsed immediately with $5 \mathrm{ml}$ of isotonic ammonium formate to remove salt before measuring dry weights. All filters were put on ice and then frozen at $-20^{\circ} \mathrm{C}$ until analysis.

Chl a samples were collected on $25 \mathrm{~mm}$ GF/F filters using a Millipore ${ }^{\circledR} 12$ Sampling Holder Vacuum Manifold. Depending upon the conditions of the water, 100 to $200 \mathrm{ml}$ of water were filtered. For each sampling site, $2 \mathrm{chl}$ a filters were folded immediately into aluminum foil and stored on ice. At the laboratory, filters were frozen at $-20^{\circ} \mathrm{C}$ until analysis.
Sediment cores were collected in July, August, September, and November 2010 around the FLUPSY (15 cores), in mid-estuary near the marina (360 to $420 \mathrm{~m} ; 4$ cores), and near or in the salt marsh (6 cores; Fig. 1) using a Wildo Core sampler with a core length of $53.4 \mathrm{~cm}, 5.1 \mathrm{~cm}$ outer diameter, and $4.6 \mathrm{~cm}$ inner diameter. Core collection near the FLUPSY did not require a boat, so we were able to take more samples there than at the salt marsh and mid-estuary sites, where collection depended on boat availability. For each location, duplicate cores were taken: one to determine dissolved oxygen and $\mathrm{pH}$ and to be immediately sectioned for total ammonia, and the other core was taken on ice to the laboratory for hydrogen sulfide analysis. Cores were not taken at the mouth of the embayment because yearly dredging of this site disturbed sediment profiles.

A MI-414 pH electrode in a 16 gauge needle was used to obtain millimeter-scale resolution for $\mathrm{pH}$. Dissolved oxygen in the core was determined with an oxygen micro-optical, $140 \mu \mathrm{m}$ probe in a needle (Loligo Systems). Each probe was attached to a micro-manipulator for millimeter-scale resolution of each variable. The advantages of using micro-electrodes over chamber methods include a fast response time, in situ measurements, and fine resolution $(100 \mu \mathrm{m})$, so that these measurements reflect processes taking place in the sediments at the time of collection (Kemp et al. 1993). Oxygen and $\mathrm{pH}$ measurements were determined in the overlying water and for the first $10 \mathrm{~mm}$ of each core, which was the maximum depth accessible with the microelectrodes. After the cores were analyzed for $\mathrm{pH}$ and dissolved oxygen, the entire core was sectioned into $2 \mathrm{~cm}$ intervals to provide enough pore water for total ammonia analysis. Sectioned sediments were put in $50 \mathrm{ml}$ centrifuge tubes and centrifuged at $1000 \times g$ for $20 \mathrm{~min}$ to obtain the pore water. The pore water was decanted and filtered through a $0.45 \mu \mathrm{m}$ filter, with the effluent being collected into $15 \mathrm{ml}$ centrifuge tubes that were immediately put on ice in the dark for subsequent total ammonia determination. Sediment was left in the centrifuge tube to be sieved for grain size and for analysis of particulate nitrogen, carbon, and sulfur.

For hydrogen sulfide analysis, the second sediment core was sectioned at $10 \mathrm{~mm}$ intervals within $12 \mathrm{~h}$ of collection in a Captair pyramid 2220 nitrogen-filled glove bag. The sections were put in $50 \mathrm{ml}$ centrifuge tubes and centrifuged at $1000 \times g$ for $20 \mathrm{~min}$. Once centrifuged, each sub-sample was taken back to the glove bag to be filtered through a $0.45 \mu \mathrm{m}$ filter, with 
the effluent collected into a $15 \mathrm{ml}$ tube and preserved with $0.05 \mathrm{~g} \mathrm{ml}^{-1}$ of zinc acetate $(1 \%$ of final sample volume). Samples were analyzed for hydrogen sulfide the next day using the spectrometric method of Cline (1969). Even though the cores were stored on ice, sectioned immediately, and preserved for hydrogen sulfide analysis at the laboratory, time until analysis usually was $14 \mathrm{~h}$. Therefore, to make sure that hydrogen sulfide was not being lost during transport, sediment cores from July 2010 were analyzed in the field to determine hydrogen sulfide with voltammetric micro-electrodes (Brendel \& Luther 1995) that were available for use during this sampling trip. These electrodes allowed for in situ, fineresolution hydrogen sulfide measurements in sediments, versus the sectioning method which was done every $10 \mathrm{~mm}$. Final flux calculations from the Cline (1969) method and the microelectrodes were similar to each other.

\section{Analytical procedures}

Total ammonia, nitrate+nitrate, phosphate, and silicate were determined within $24 \mathrm{~h}$ of sample collection using a Quattro autoanalyzer (Seal Analytical) following methods in Hansen \& Koroleff (1999). Briefly, total ammonia was determined using the Berthelot reaction (detection limit: $0.05 \mu \mathrm{M}$ ). For nitrate+nitrite, a cadmium column was used to reduce nitrate to nitrite, and then the formation of the red azo dye was used (detection limit: $0.05 \mu \mathrm{M}$ ). The phosphomolybdate heteropoly acid reduced to a blue compound was used to determine phosphate (detection limit: $0.01 \mu \mathrm{M}$ ), and the formation of $\beta$-silicomolybdic acid was used to determine silicate (detection limit: $0.10 \mu \mathrm{M}$ ).

TSM filters were dried in an oven $\left(60^{\circ} \mathrm{C}\right)$ overnight and then weighed. Chl a was measured fluorometrically. Sample filtration and extraction followed Li et al. (2009), and fluorescence was measured with a Luminescence Spectrometer LS 50B (PerkinElmer). The maximum fluorescence was read at $660 \mathrm{~nm}$. The excitation wavelength was $417 \mathrm{~nm}$. The fluorescence versus chl a concentration was calibrated with a chl a standard (Sigma-Aldrich).

Particulate carbon, nitrogen, and sulfur were determined on a Costech ECS 4010 CHNS elemental analyzer. All samples were dried in an oven $\left(60^{\circ} \mathrm{C}\right)$ overnight. Filters were then fumed with concentrated hydrochloric acid for $48 \mathrm{~h}$ to determine organic carbon and nitrogen. Sediments were ground using a planetary ball mill (Retsch PM 200) to $63 \mu \mathrm{m}$. Sub- samples of $\sim 3 \mu \mathrm{g}$ of sediment were weighed into tin boats with $\sim 1.5 \mu \mathrm{g}$ of vanadium oxide added for total carbon, nitrogen, and sulfur determination. A subset of the sediments was also fumed with hydrochloric acid for determination of organic carbon and nitrogen with the elemental analyzer. During all runs, a standard reference material (SRM 8704 Buffalo River Sediment) was analyzed with the samples, with a reported total carbon value of $3.35 \%$. Our recovery for total carbon was $3.15 \pm 0.33 \%(n=50)$ with our sample analysis, which is within the reported SRM value range.

\section{Flux calculations}

Sediment oxygen, hydrogen sulfide, and total ammonia were calculated using Fick's First Law of Diffusion (Berner 1980) that Emerson et al. (1984) and Hammond et al. (1985) used for shallow-water, estuarine sediments. The assumption is that molecular diffusion was the major component in the exchange of dissolved substances between the bottom sediments and overlying water; this can be expressed as:

$$
J=-\varphi^{m} \cdot D_{\mathrm{s}} \cdot \frac{\partial C}{\partial z}
$$

where $J$ is the flux, $\varphi$ is the porosity, $m$ has a value of 3 for these surface sediments (Ullman \& Aller 1982), $D_{\mathrm{s}}$ is the effective diffusion coefficient, and $\partial C / \partial z$ is the observed concentration gradient of pore water. Molecular diffusion coefficients in seawater were corrected for the in situ, bottom-water temperature.

Based upon the above flux calculations, the average flux that the sediments provide to the embayment can be calculated. Using the area of the embayment ( $105 \mathrm{~m}$ wide by $640 \mathrm{~m}$ long) we calculated the amount of total ammonia fluxing from the sediments, and compared it to fluxes from the FLUPSY and the salt marsh.

Having fixed stations in the embayment allows for geographical inputs to be highlighted. By using the fixed station in the salt marsh, we calculated the fluxes of nutrients, TSM, and chl a into the embayment from this source. To do flux estimates of nutrients, TSM, and chl $a$, the concentration in the salt marsh was multiplied by the discharge rate from the salt marsh $\left(5 \mathrm{~m}^{3} \mathrm{~s}^{-1}\right)$.

Using the difference between the input and the output of the FLUPSY, a removal or input flux to the embayment was calculated. The pumping rate of $1.32 \times 10^{5} 1 \mathrm{~h}^{-1}$ for the FLUPSY was used to calculate the removal/input from the FLUPSY. 


\section{Statistics}

All statistics were run with Stagraphics Plus (originally Manugistics, now StatPoint). A paired $t$-test was used to determine if there was a significant difference between the FLUPSY input and output data. If there was a significant difference, then the difference between the input and output was calculated (all data reported as mean $\pm \mathrm{SE}$ ). Since test assumptions of normality (Shapiro-Wilk test) and homogeneity of data (Bartlett test) were met (see Table 1), a 1-way ANOVA was run on sedimentary particulate carbon, nitrogen, and sulfur, and on the flux of oxygen, hydrogen sulfide, and total ammonia from the pore water. Since there were not enough data to analyze seasonal variation in total ammonia sediment flux for all sites, statistical analysis for this variable were limited to the FLUPSY site, where most of the sediment cores were taken.

\section{RESULTS}

\section{FLUPSY water chemistry}

There was no difference in salinity $\left(t_{11}=1.25, \mathrm{p}=\right.$ $0.48)$, water temperature $\left(t_{11}=0.58, \mathrm{p}=0.36\right)$, phosphate $\left(t_{11}=1.40, \mathrm{p}=0.21\right)$, or silica $\left(t_{11}=-0.05, \mathrm{p}=\right.$ 0.48 ) between the inflow and outflow of the FLUPSY (data not shown). There were, however, differences in TSM, chl $a$, total ammonia, and nitrate+nitrite (data not shown); negative numbers mean that the output had a lower concentration than the input (net removal), and positive numbers indicate that the FLUPSY was adding the constituent (net input). From June until November, there was net removal of TSM $(-2.53 \pm 0.51 \mathrm{mg}$ $\left.\mathrm{l}^{-1} ; t_{24}=1.41, \mathrm{p}=0.04\right)$ and $\mathrm{chl} a(-7.30$ $\pm 0.11 \mu \mathrm{g} \mathrm{l}^{-1} ; t_{11}=1.00, \mathrm{p}=0.02$ ) by the FLUPSY. The FLUPSY was a source of total ammonia $\left(0.16 \pm 0.15 \mu \mathrm{mol} \mathrm{l}^{-1} ; t_{11}\right.$ $=-1.00, \mathrm{p}=0.04)$ and nitrate + nitrite $\left(0.51 \pm 0.31 \mu \mathrm{mol} \mathrm{l^{-1 }} ; t_{11}=-1.68, \mathrm{p}<\right.$ $0.01)$ throughout the season.

\section{Embayment water chemistry}

All graphs are plotted from Great Peconic Bay $(0 \mathrm{~m})$ to the salt marsh $(630 \mathrm{~m})$, with the data from the
FLUPSY output at $590 \mathrm{~m}$ from the mouth of Great Peconic Bay. Throughout the study, surface salinity values ranged from 23.8 to 28.0 , and temperatures ranged from 9.2 to $28.0^{\circ} \mathrm{C}$ for the embayment (Fig. 2). There was very little variation in salinity along the length of the embayment, but the salt marsh endmember always had a slightly lower salinity than the Great Peconic Bay endmember. The salinity at the FLUPSY was similar to that found in the embayment (Fig. 2). Temperature was similar along the length of the embayment (Fig. 2). The temperature of the FLUPSY output fell within the observed temperature range of the embayment (Fig. 2).

For each of the variables (i.e. salinity, temperature, nutrients), the pattern in surface water and bottom water on all the sampling dates was similar; therefore, the surface water means and bottom water means were plotted against each other. The embayment showed a very small difference between bottom water and top water, with the bottom water having slightly higher salinity but no real difference in temperature (Fig. 3). Salinity and temperature were fairly consistent throughout the embayment for bottom and top water.

Total ammonia concentrations in the surface water ranged from undetectable to $14.44 \mu \mathrm{mol} \mathrm{N} \mathrm{^{-1 }}$ (September, Fig. 4). Total ammonia levels showed variation within the embayment, with lower concentrations in the center of the embayment compared to the salt
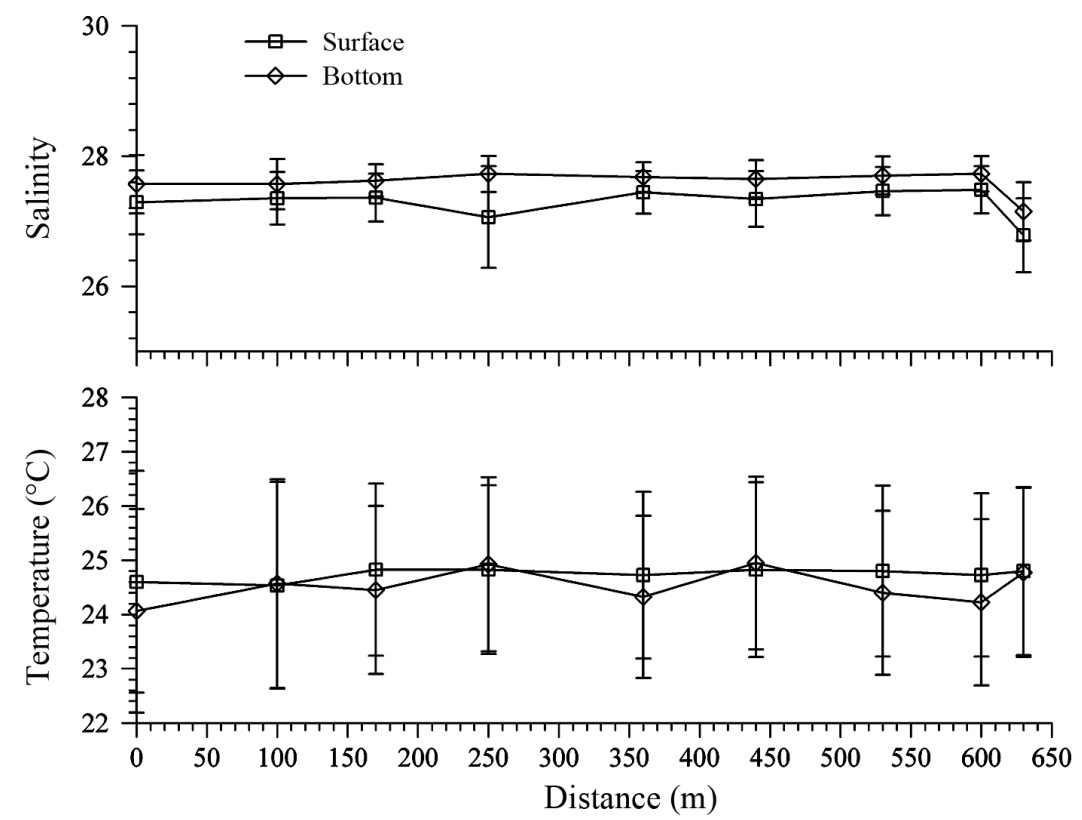

Fig. 2. Surface salinity and temperature in the East Creek embayment along a transect from Peconic Bay $(0 \mathrm{~m})$ to the salt marsh $(630 \mathrm{~m})$ from June to November 2010. $\times$ : individual measurements obtained from the output pipe of the FLUPSY on the monthly estuarine transect sampling dates and the discrete sampling dates from May to November 

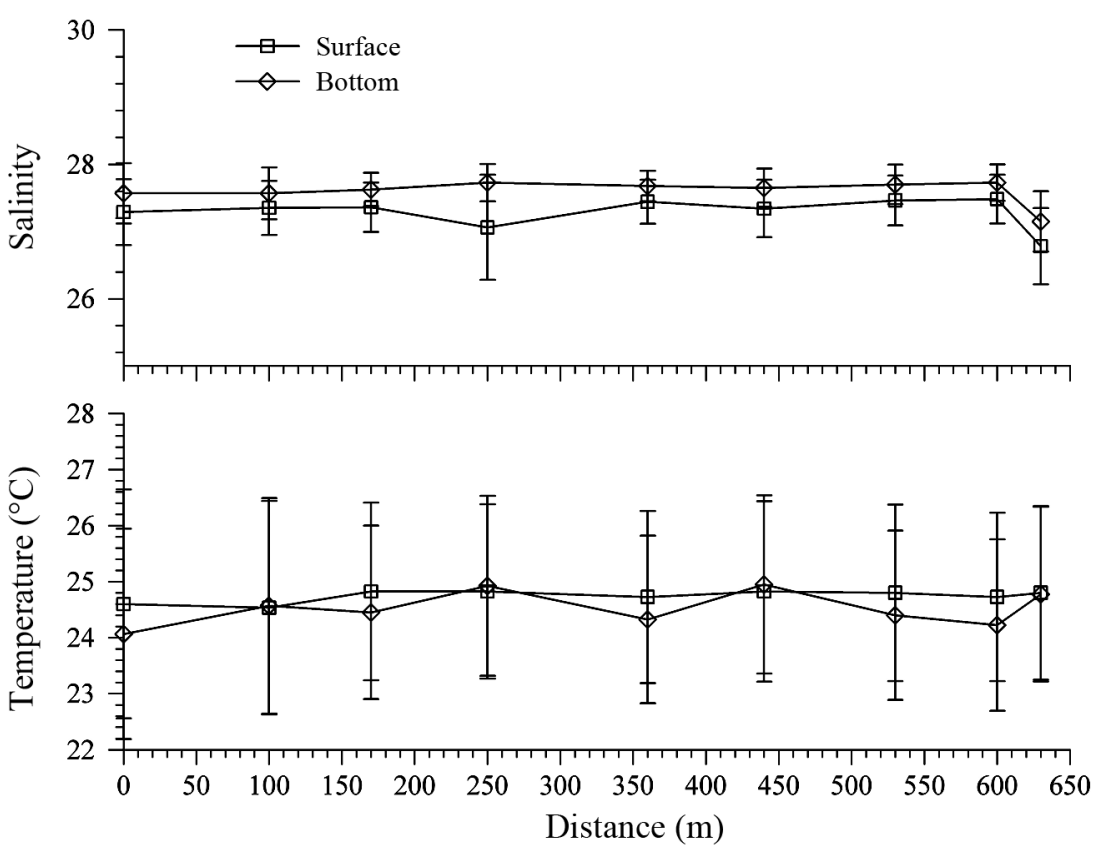

Fig. 3. Surface and bottom water salinity and temperature in the East Creek embayment along a transect from Peconic Bay $(0 \mathrm{~m})$ to the salt marsh $(630 \mathrm{~m})$. Data: mean $\pm \mathrm{SE}$ of all sampling dates

marsh and seawater endmembers. The output of total ammonia from the FLUPSY was within the concentration range observed in the embayment, with levels ranging from undetectable to $6.98 \mu \mathrm{mol} \mathrm{N}{ }^{-1}$ (Fig. 4). There was a difference in bottom and surface water total ammonia concentration, with concentrations usually lower in the surface water than in the bottom water (Fig. 5). In the bottom water, there were spikes of total ammonia at 360, 530 and $630 \mathrm{~m}$ (Fig. 5).

Nitrate+nitrite in the embayment ranged from undetectable to $149.12 \mu \mathrm{mol} \mathrm{N} \mathrm{^{-1 }}$, with an increase in concentration from Great Peconic Bay to the salt marsh (Fig. 4). The highest concentration of $149.12 \mu \mathrm{mol} \mathrm{N} \mathrm{l^{-1 }}$ was only recorded once during sampling, after a very intense rain event. Nitrate+ nitrite output from the FLUPSY ranged from undetectable to $7.88 \mu \mathrm{mol} \mathrm{N} \mathrm{l}{ }^{-1}$, which was well within the range of the rest of the embayment. Surface water concentrations were higher near the salt marsh endmember compared to the bottom water (Fig. 5)

Phosphate concentrations in surface water ranged

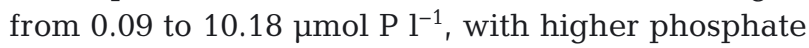
concentrations found in the seawater endmember (Great Peconic Bay) than at the salt marsh endmember (Fig. 4). Output of phosphate from the FLUPSY was within the range of phosphate concentrations determined in the embayment (Fig. 4). There were no differences in phosphate between surface and bottom water (Fig. 5).
The largest range in nutrient concentration was observed in the surface water silicate profiles (Fig. 4). Concentrations ranged from undetectable to 121.22 $\mu \mathrm{mol} \mathrm{Si} \mathrm{l}^{-1}$; however, there was very little difference between the Great Peconic Bay endmember and the salt marsh endmember on each sampling date. The output from the FLUPSY was well within the range of silicate concentrations found in the embayment (Fig. 4). There were no differences in silicate between surface and bottom waters (Fig. 5).

Concentration of TSM varied from 2.0 to $44.4 \mathrm{mg} \mathrm{l}^{-1}$ in the embayment (Fig. 6). TSM concentration in the output from the FLUPSY was usually similar to that found in the salt marsh; however, there were 2 occasions when the TSM concentration in the FLUPSY outflow was higher than anywhere else in the embayment (Fig. 6). TSM concentrations were higher in surface water than in bottom water from the 0 to $400 \mathrm{~m}$ sampling locations, but were lower than in bottom water from $400 \mathrm{~m}$ to the salt marsh for all the embayment transects (Fig. 7).

Chl a concentrations ranged from 2.13 to $35.88 \mu \mathrm{g}$ $\mathrm{l}^{-1}$ considering all sampling dates (Fig. 6). Chl a concentrations varied on each sampling date, with concentrations at the FLUPSY usually within the range found in the rest of the embayment. On 2 occasions, however, there were higher chl $a$ values at the output than were found in the embayment (Fig. 6). Chl a concentrations were lower in bottom water than in surface water (only 3 samples were available for analysis; data not shown).

There was very little difference between the measured particulate $\mathrm{C}: \mathrm{N}$ ratios in the water column among the sampling dates (Fig. 6), but the ratio was usually above the Redfield ratio of 6.6. The FLUPSY output into the embayment had mean seston C:N ratios of $6.59 \pm 0.23$, exactly the ratio of Redfield and much lower than the rest of the embayment (mean C:N ratio of all data points: $7.82 \pm 0.19$; Fig. 6 ).

\section{Sediment}

Grain size analysis classified sediment from the salt marsh as fine sand (mean $\varphi=2.3$ ), whereas the sites located in the embayment and near the FLUPSY 


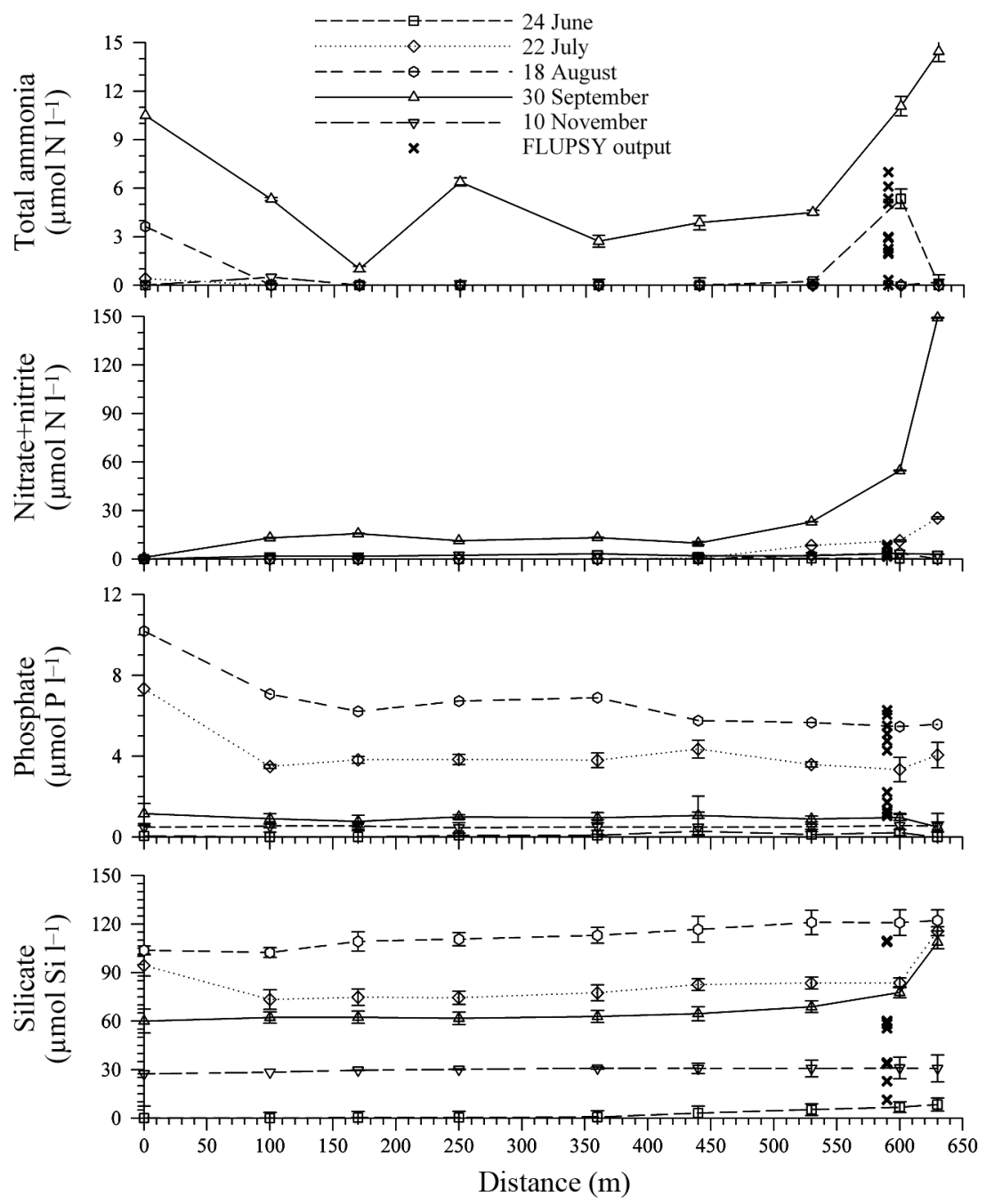

Fig. 4. Surface total ammonia, nitrate+nitrite, phosphate, and silicate, in the East Creek embayment along a transect from Peconic Bay $(0 \mathrm{~m})$ to the salt marsh $(630 \mathrm{~m})$ from June to November 2010. x: individual measurements obtained from the output pipe of the FLUPSY on the monthly estuarine transect sampling dates and discrete sampling dates from May to November. Data: mean $\pm \mathrm{SD}$ ments ranged from 0.01 to $0.15 \%$ at all sampling locations, and there was no significant difference between sampling locations (Table 1). The average sulfur content was $0.08 \pm 0.01 \%$.

The $\mathrm{pH}$ in the sediments ranged from 6.8 to 7.7 , with the highest surface sediment $\mathrm{pH}$ recorded at the salt marsh sites and the lowest at the FLUPSY sites (Fig. 8). For the midestuary and FLUPSY sites, pH changed very little in the first $10 \mathrm{~mm}$ from the sediment surface, whereas there was a slight decrease in $\mathrm{pH}$ with sediment depth at the salt marsh site (Fig. 8). Sediment oxygen levels at the midestuary and FLUPSY sites were very low, with no detectable oxygen deeper than $1 \mathrm{~mm}$. In contrast, oxygen levels remained high down to $9 \mathrm{~mm}$ depth at the salt marsh location (Fig. 8). Hydrogen sulfide concentrations were undetectable in the overlying water at the mid-estuary and salt marsh sites but not at the FLUPSY site (Fig. 8). Concentrations of hydrogen sulfide increased with sediment depth at all sampling locations, but the highest hydrogen sulfide concentrations were found at the FLUPSY site (Fig. 8).

Sediment pore water total ammonia concentrations at the salt marsh site were low $\left(<30 \mu \mathrm{mol} \mathrm{l}^{-1}\right)$, whereas at the FLUPSY and mid-estuary locations total ammonia concentrations were $>100 \mathrm{mmol} \mathrm{l}^{-1}$ (Fig. 8). In the salt marsh, maximum total ammonia oc- were classified as very fine sand (means of $\varphi=3.6$ and $\varphi=3.7$, respectively). Organic carbon concentration in the surface sediments $(0$ to $2 \mathrm{~cm}$, the active layer) ranged from 0.57 to $6.71 \%$. There was no significant difference in organic carbon concentration between the mid-estuary, FLUPSY, and salt marsh sites (Table 1), with an overall mean surface organic carbon concentration of $4.94 \pm 0.61 \%$. For total sediment nitrogen, the concentration ranged from 0.03 to $0.64 \%$ throughout East Creek. There was no significant difference in the particulate nitrogen between sampling locations (Table 1), with an overall mean of $0.21 \pm 0.03 \%$. The $\mathrm{C}: \mathrm{N}$ ratio of the sediment was higher than that in the water column (Fig. 6), with a mean of $23.84 \pm 1.45$. The sulfur content in the sedi-
Table 1. Results of the Shapiro-Wilk test of normality, Bartlett's test of homogeneity of variance, and ANOVA for differences in sedimentary particulate carbon, nitrogen, and sulfur, and pore water fluxes of oxygen, hydrogen sulfide, and ammonia to the water column among different sampling locations (FLUPSY, mid-estuary, and salt marsh) in the East Creek embayment (see Fig. 1)

\begin{tabular}{|lcccccc|}
\hline \multirow{2}{*}{ Variable } & \multirow{2}{*}{$\begin{array}{c}\text { Shapiro-Wilk } \\
\mathrm{p}\end{array}$} & \multicolumn{2}{c|}{ Bartlett } & \multicolumn{2}{c|}{ ANOVA } \\
& $\mathrm{p}$ & $F$ & $\mathrm{df}$ & $\mathrm{p}$ \\
\hline Particulate carbon & 0.98 & 0.49 & 0.16 & 5,15 & 0.85 \\
Particulate nitrogen & 0.96 & 0.17 & 0.36 & 5,15 & 0.70 \\
Particulate sulfur & 0.92 & 0.33 & 0.12 & 5,15 & 0.88 \\
Oxygen flux & 0.91 & 0.53 & 0.51 & 5,15 & 0.75 \\
Hydrogen sulfide flux & 0.07 & 0.06 & 0.70 & 3,8 & 0.42 \\
Total ammonia flux & 0.16 & 0.66 & 1.60 & 5,15 & 0.21 \\
\hline
\end{tabular}




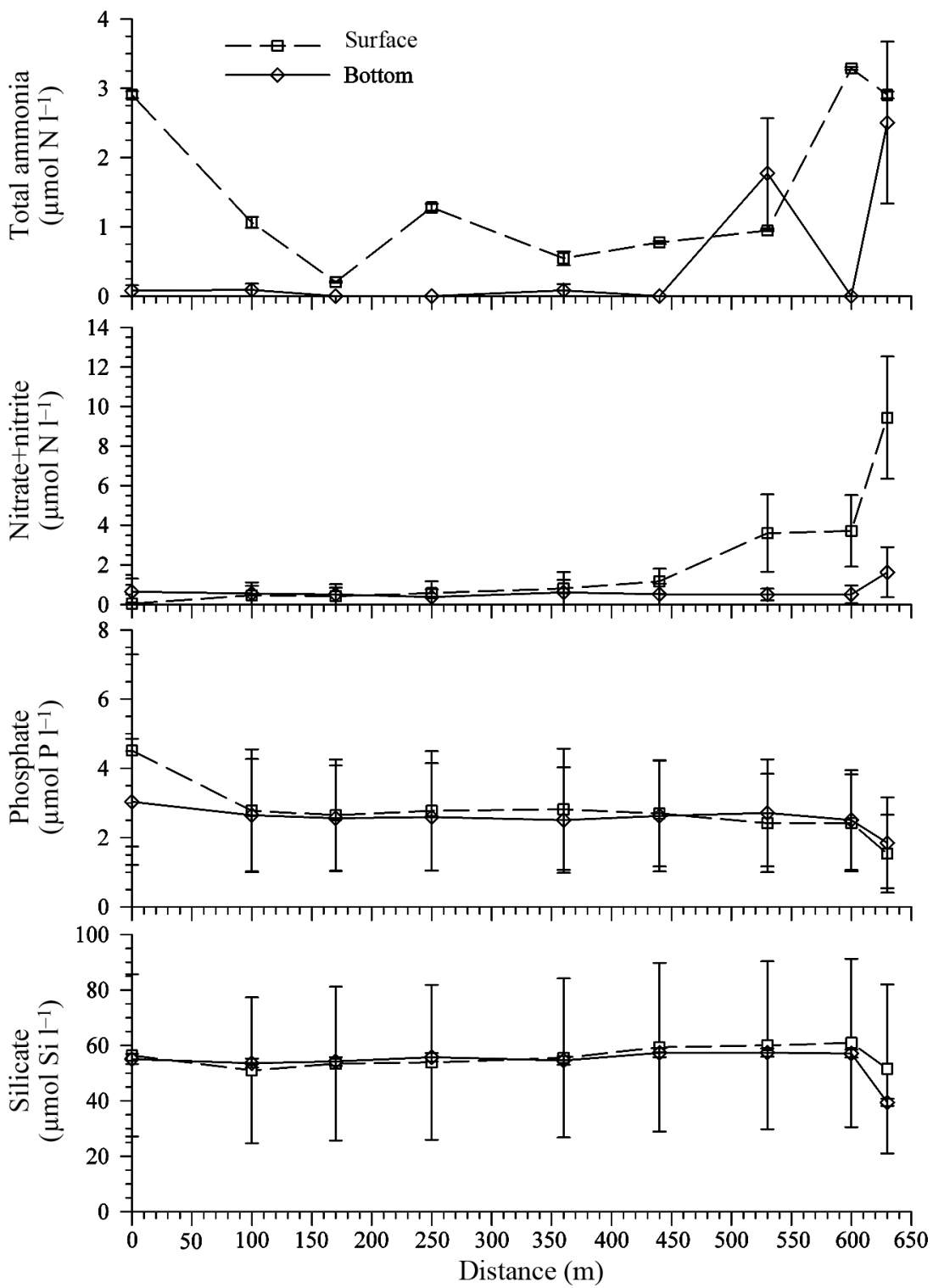

Fig. 5. Surface water and bottom water total ammonia, nitrate+nitrite, phosphate, and silicate in the East Creek embayment along a transect from Peconic

Bay $(0 \mathrm{~m})$ to the salt marsh $(630 \mathrm{~m})$. Data: mean \pm SE of all sampling dates

$75.25 \pm 5.73 \mu \mathrm{mol} \mathrm{m} \mathrm{m}^{-2} \mathrm{~h}^{-1}$ at the FLUPSY, and from $3.27 \pm 2.10$ to $73.12 \pm 3.33 \mu \mathrm{mol} \mathrm{m} \mathrm{m}^{-2} \mathrm{~h}^{-1}$ at the salt marsh. The mid-estuary sites had oxygen fluxes into the sediments from $22.54 \pm 2.19$ to $55.09 \pm 4.48 \mu \mathrm{mol} \mathrm{m} \mathrm{m}^{-2}$ $\mathrm{h}^{-1}$. There was no significant difference in the flux of oxygen among the 3 sites (Table 1).

Hydrogen sulfide flux from the sediments varied from $13.37 \pm 1.25$ to $376.07 \pm 10.25 \mu \mathrm{mol} \mathrm{m} \mathrm{m}^{-2} \mathrm{~h}^{-1}$ at the FLUPSY, and from $0.08 \pm 0.19$ to $92.32 \pm 9.87 \mu \mathrm{mol} \mathrm{m} \mathrm{m}^{-2} \mathrm{~h}^{-1}$ at the salt marsh. Flux at these 2 sites was similar (Table 1). The mid-estuary sediment sites had a similar flux of hydrogen sulfide out of the sediments $(11.34 \pm 2.36$ $\mu \mathrm{mol} \mathrm{m} \mathrm{m}^{-2} \mathrm{~h}^{-1}$ ), but only 2 samples were available, therefore no statistical analysis comparing all 3 areas of the embayment was performed.

At most of the sampled locations, total ammonia was fluxing out of the sediments at a mean rate of $0.19 \pm$ 0.25 to $48.31 \pm 3.52 \mu \mathrm{mol} \mathrm{m}{ }^{-2} \mathrm{~h}^{-1}$ at the FLUPSY, $0.21 \pm 0.11$ to $73.46 \pm$ $5.52 \mu \mathrm{mol} \mathrm{m} \mathrm{m}^{-2} \mathrm{~h}^{-1}$ at the mid-estuary sites (360 to $420 \mathrm{~m})$, and $0.01 \pm 0.03$ to $3.95 \pm 0.56 \mu \mathrm{mol} \mathrm{m} \mathrm{m}^{-2} \mathrm{~h}^{-1}$ in the salt marsh. Flux of total ammonia did not significantly differ between sampling locations (Table 1). There were not enough data to determine if there was seasonal variability in the flux of total ammonia, except at the FLUPSY location where sediment samples were taken more often. There, higher ammonia fluxes occurred in the sediment during late summer and fall

curred between 2 and $4 \mathrm{~cm}$ depth, followed by a decrease in concentration with depth (Fig. 8 and data from other sampling dates [not shown]). At both the mid-estuary and FLUPSY sites, total ammonia concentration in sediment pore water increased with depth (Fig. 8). The mid-estuary locations had higher total ammonia concentrations than the FLUPSY site (Fig. 8).

\section{Flux data}

Oxygen was fluxing into the sediments. The oxygen flux into the sediments varied from $7.39 \pm 2.14$ to
(August to November) than during late spring and early summer (May to July) $\left(F_{4,7}=11.33, \mathrm{p}=0.01\right.$; data not shown).

The inputs from the salt marsh varied greatly throughout the sampling season, but overall, the salt marsh was a source of total ammonia, nitrate+nitrite, phosphate, silicate, TSM, and chl a to the embayment (Table 2). By contrast, the FLUPSY removed TSM and chl a from the embayment, while adding total ammonia and nitrate+nitrite (Table 2). Using the overall mean sediment flux for total ammonia (for all 3 locations; Table 2), the sediments provide $28.95 \pm$ $43.46 \mathrm{~mol} \mathrm{~d}^{-1}$ of $\mathrm{N}$ as total ammonia to the embayment. 


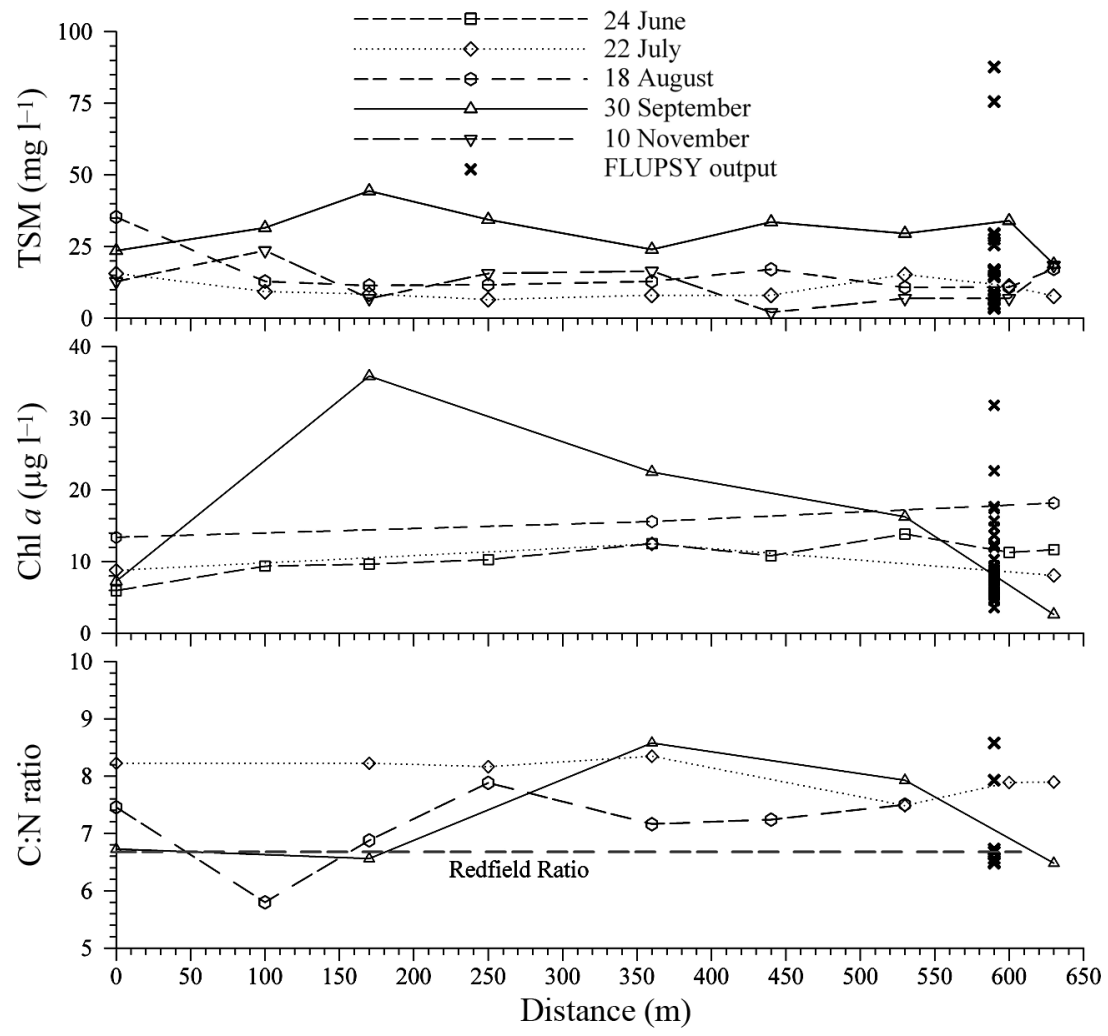

Fig. 6. Surface chlorophyll a, total suspended material (TSM), and organic carbon:nitrogen $(\mathrm{C}: \mathrm{N})$ ratio in the East Creek embayment along a transect from Peconic Bay $(0 \mathrm{~m})$ to the salt marsh $(630 \mathrm{~m})$ from June to November 2010. x: measurements obtained from the output pipe of the FLUPSY on the monthly estuarine transect sampling dates and discrete sampling dates from May to November. Grey dashed line: Redfield ratio. Note: not all dates are shown in each panel due to lost data

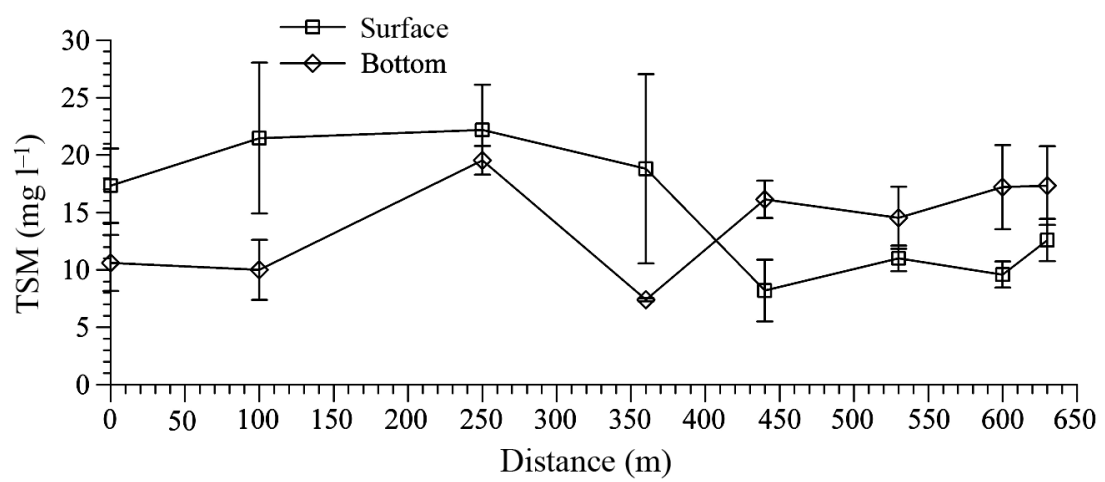

Fig. 7. Surface water and bottom water concentrations of total suspended material (TSM) in the East Creek embayment, from Peconic Bay $(0 \mathrm{~m})$ to the salt marsh $(630 \mathrm{~m})$. Data: mean $\pm \mathrm{SE}$ of all sampling dates

\section{DISCUSSION}

\section{FLUPSY}

The output from the FLUPSY was always within the range detected in the embayment for total ammo- nia, nitrate+nitrite, phosphate, and silicate (Fig. 4). For TSM, chl $a$, and organic C:N ratio, however, the station near the FLUPSY occasionally had different concentrations than in the embayment (Fig. 6). Chl a concentrations were occasionally greater at the station near the FLUPSY than in the embayment, and organic particulate $\mathrm{C}: \mathrm{N}$ ratios were closer to Redfield ratios at this station compared to the rest of the embayment (Fig. 6).

The data on inflow and outflow of the FLUPSY indicated that it was removing TSM and chl $a$ from the water column; however, data from each estuarine transect sampling suggest that the station next to the FLUPSY had slightly higher TSM, chl $a$, and seston Redfield ratio relative to other stations within the embayment throughout the season (Fig. 6). The absence of detectable inorganic nitrogen data during most of the sampling season suggests that the phytoplankton community in the embayment was limited in nitrogen. Even though we used the fixed-station method of estuarine transect sampling (which highlights the output of the FLUPSY into the embayment), we were never able to detect a strong source of nitrogen at either of the stations sampled near the FLUPSY $(10 \mathrm{~m}$ upstream and $50 \mathrm{~m}$ downstream of the FLUPSY outflow; Fig. 4). This suggests that recycling of nutrients was occurring very quickly, and concentration differences could not be measured with the discrete samples taken in this study. The nutrient data combined with the TSM and chl a data suggest that local regeneration of nutrients near the FLUPSY site might be occurring, allowing for a higher local biomass of phytoplankton (Wikfors 2011). The occasional increase in chl $a$ at the stations near the FLUPSY, potentially from the regeneration of nutrients, is consistent with what is observed in waters with dense, natural populations of bivalves: the nitrogen in ingested food is partially excreted as urine (Bayne et al. 1976, Bayne \& Hawkins 1992), which increases the dissolved nitrogen pool supporting new phytoplankton production 

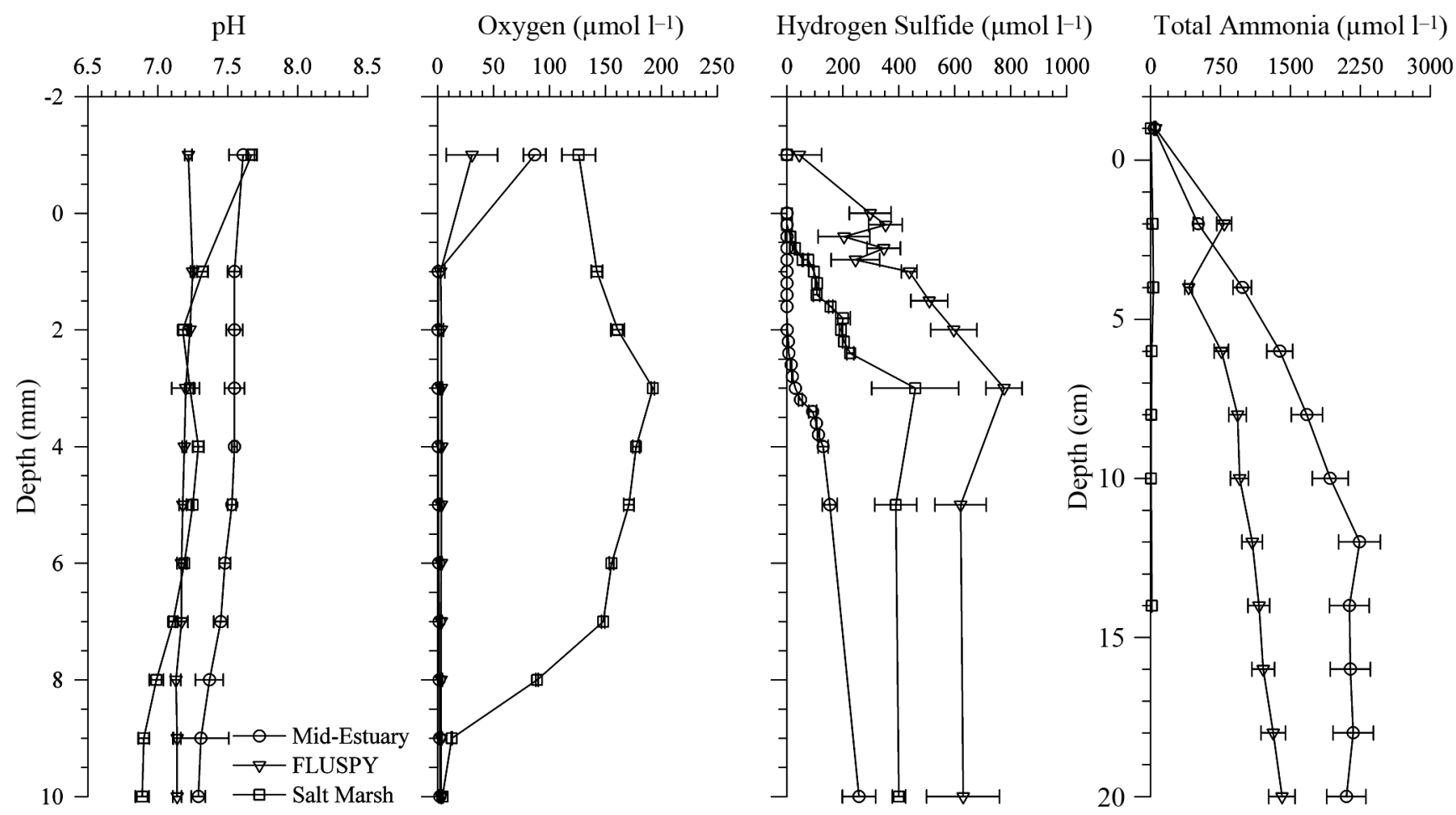

Fig. 8. Sediment depth profiles of pH, oxygen, hydrogen sulfide, and total ammonia at each of the 3 sediment sampling locations (mid-estuary, FLUPSY, and salt marsh) for 13 July 2010. Data: mean \pm SD of duplicate samples from a representative site at each location

Table 2. Total sedimentary flux estimates from the salt marsh $(n=6)$, the FLUPSY $(n=15)$, and mid-estuary $(n=4)$ sediments in the East Creek embayment. A negative sign indicates that there was net removal, while positive values indicate net input into the embayment. Data: mean \pm SE of all sediment sites (see Fig. 8) per sampling location (source); TSM: total suspended material; ND: not determined

\begin{tabular}{|c|c|c|c|c|c|c|}
\hline Source & $\begin{array}{l}\text { Total ammonia } \\
\quad\left(\mathrm{mol} \mathrm{d}^{-1}\right)\end{array}$ & $\begin{array}{l}\text { Nitrate+nitrite } \\
\quad\left(\mathrm{mol} \mathrm{d}^{-1}\right)\end{array}$ & $\begin{array}{l}\text { Phosphate } \\
\left(\mathrm{mol} \mathrm{d}^{-1}\right)\end{array}$ & $\begin{array}{l}\text { Silicate } \\
\left(\mathrm{mol} \mathrm{d}^{-1}\right)\end{array}$ & $\begin{array}{l}\text { TSM } \\
\left(\mathrm{g} \mathrm{d}^{-1}\right)\end{array}$ & $\begin{array}{l}\text { Chl a } \\
\left(\mathrm{g} \mathrm{d}^{-1}\right)\end{array}$ \\
\hline Salt marsh & $0.51 \pm 0.48$ & $15329.95 \pm 13911.75$ & $1080.66 \pm 540.33$ & $23051.20 \pm 11525.60$ & $7171.20 \pm 1392.26$ & $2818.94 \pm 1409.47$ \\
\hline FLUPSY & $28.95 \pm 15.48$ & $1.62 \pm 0.98$ & ND & ND & $-8.02 \pm 1.62$ & $-23.13 \pm 0.25$ \\
\hline Mid-estuary & $57.39 \pm 114.42$ & ND & ND & ND & ND & ND \\
\hline
\end{tabular}

(Kaspar et al. 1985, Asmus \& Asmus 1991, Swanberg Lindström 1991) and a net gain in phytoplankton productivity (Asmus \& Asmus 1991).

Overall, the FLUPSY was a source of total ammonia and nitrate+nitrite to the embayment. The FLUPSY, however, was a very minor source of total ammonia when compared to the salt marsh and sediments $(0.04 \%$ and $1.76 \%$ of their input, respectively; Table 2). Compared to the salt marsh, the FLUPSY was only a $<0.01 \%$ source of nitrate+nitrite to the embayment (Table 2). For TSM and chl $a$, the FLUPSY was removing $0.11 \%$ of the TSM compared to the amount coming in from the salt marsh, and $0.82 \%$ of the chl $a$ (Table 2). The FLUPSY represented a higher percentage of removal than of inputs relative to the other sources affecting the embayment.

\section{Water column}

Even though the embayment is only $640 \mathrm{~m}$ long and $3 \mathrm{~m}$ deep, salinity and nutrient patterns indicate that some stratification was almost always present during sampling (Figs. $3 \& 5$ ). Accordingly, this area is classified as a microtidal (tide $<2 \mathrm{~m}$ ), partiallymixed embayment (Davies 1964, Hayes 1975) that discharges into Great Peconic Bay. The stratification of the water column makes the behavior of the nutrients complex. Processes affecting the surface water concentrations can be distinctly different than those affecting the bottom water. Surface-water concentrations are likely influenced more by freshwater inputs (the salt marsh) and utilization by the planktonic community, whereas bottom-water concentrations of 
nutrients will be influenced more by tidal inputs, biological benthos utilization, and sediment processes (fluxes in or out; Rozan et al. 2002).

To determine if conservative or non-conservative mixing was occurring in the embayment, a line (not shown) can be drawn between the salt marsh endmember $(630 \mathrm{~m})$ and the Great Peconic Bay endmember $(0 \mathrm{~m})$. If conservative mixing was occurring, all the data points in the embayment would fall on this line, meaning no net production or utilization within the embayment (Loder \& Reichard 1981, Lin et al. 2012). If non-conservative behavior occurred, data points above the line would indicate net production, while data points below the line would indicate net removal of a constituent (Loder \& Reichard 1981, Lin et al. 2012). Total ammonia, nitrate+nitrite, and silicate behaved non-conservatively during the sampling period, with overall net removal of these nutrients from the East Creek embayment. By contrast, phosphate behaved conservatively in the embayment. The temporal variability and concentrations of total ammonia, nitrate+nitrite, phosphate, and silicate were consistent with other embayments in North America (Nixon \& Pilson 1983, Chen et al. 2010).

The removal of total ammonia, nitrate+nitrite, and silicate from the embayment can be attributable to: (1) removal by microbial processes, (2) dilution by another source of freshwater (i.e. another endmember, possibly large ground-water inputs), and (3) removal at the sediment-water interface. The removal of these nutrients at the sediment-water interface is highly unlikely because of stratification in the estuary. Furthermore, flux calculations indicate that total ammonia was fluxing out of the sediments, making the sediments a source of this nutrient, not a sink. Dilution by ground-water inputs would be possible; however, then salinity would be expected to behave non-conservatively in the bottom water, which was not observed. Consequently, the non-conservative behavior of total ammonia, nitrate+nitrite, and silicate is most likely attributable to microbial processes (i.e. phytoplankton uptake and organic matter decomposition). Chl a concentrations indicate that production of phytoplankton might be occurring within the embayment (Fig. 6), suggesting that the low nutrient concentrations were, in fact, from phytoplankton utilization. Phosphate was the only nutrient that behaved conservatively, indicating that phytoplankton growth was not limited by phosphate, but most likely limited by nitrogen or sometimes by silicate, which was often undetectable (Fig. 4). Dissolved nitrogen concentrations were often undetectable, and the seston organic C:N ratio was always greater than the Redfield ratio of 6.6, further indicating that phytoplankton growth might be limited by nitrogen in the embayment (Fig. 6).

\section{Sediment}

For the embayment, the sediments were a source of hydrogen sulfide and total ammonia to the water column, which resulted in the sediments being classified as hypoxic sulfidic sediments (Hargrave 2010). Release of hydrogen sulfide from marine sediments is an essential part of the sulfur cycle, with release occurring during the anaerobic decomposition of organic material (i.e. $1 \%$ dry sediment wt is proteinbound sulfur). There was no significant difference in hydrogen sulfide among the sampling locations along the main axis of the embayment, and, as with most marine estuarine sediments, hydrogen sulfide was fluxing out of the sediments. The hydrogen sulfide fluxes from these sediments were similar to those reported in other marine sediments (Jørgensen \& Parkes 2010).

For total ammonia, the conversion of organic nitrogen normally results in the release of nitrogen gas; however, in highly organic environments this process is often stopped at the conversion to total ammonia (Seitzinger 1988, Wallmann et al. 2006). Total ammonia is easily recycled via the pore water into the water column because of high solubility. For seawater, the United States Environmental Protection Agency has a toxicity criterion of $42 \mu \mathrm{mol} \mathrm{l}^{-1}$ of total ammonia in marine waters (USEPA 1989). Bottomand surface-water concentrations never exceeded 0.5 and $15.12 \mu \mathrm{mol} \mathrm{l}^{-1}$, respectively, indicating that despite a large flux of total ammonia from the sediments (highest $73.46 \pm 5.25 \mu \mathrm{mol} \mathrm{m}^{-2} \mathrm{~h}^{-1}$ ), concentrations of local dissolved total ammonia were below the EPA toxicity level not toxic to organisms within the embayment. The total ammonia flux from East Creek sediments was in the same order of magnitude as that from other estuarine and coastal marine sediments in non-aquacultured areas (Bailey 2005, Valdemarsen et al. 2010), and was lower than fluxes recorded beneath aquacultured mussels and clams suspended from long lines (Nizzoli et al. 2011).

In most coastal ecosystems, regeneration of nutrients and degradation of particulate organic matter (POM) in sediments is controlled by many factors, including: (1) the amount of POM produced in the surface water (Nixon 1981, Jensen et al. 1990), (2) how much degradation occurs before particles reach the sediments, (3) temperature, (4) how much oxygen is available (Seitzinger 1988, Kemp et al. 
1990, Sundby et al. 1992), and (5) sediment texture (Westrich \& Berner 1984). In the oxic zone, oxygen is the terminal electron acceptor, whereas in anoxic sediments, there is a small nitrate reduction zone followed by sulfate reduction. Typically, in oxic sediments, nitrification by bacteria results in the production of nitrogen gas and nitrate, which dissolves into sediment pore water and overlying seawater. Any gaseous nitrogen is lost from the water to the atmosphere and is thus removed as a potential nutrient for primary producers. Furthermore, in estuarine environments with high hydrogen sulfide concentrations (anoxic sediments), the hydrogen sulfide can inhibit nitrification/denitrificaiton of nitrogen to nitrogen gas (Newell et al. 2002, Newell 2004, Batley \& Simpson 2009). When this happens, nitrogen becomes regenerated solely as total ammonia and is often returned to the water column to stimulate further phytoplankton production (Newell et al. 2002, Newell 2004, Burkholder \& Shumway 2011). For all sites at East Creek, there was a high flux of hydrogen sulfide and total ammonia from sediments to the water column, suggesting that microbial nitrification/denitrification of organic matter was being inhibited (Fig. 8). At the FLUPSY, the flux of total ammonia from the sediments to the water column was most likely utilized by phytoplankton. Furthermore, Rozan et al. (2002) showed that in small enclosed embayments, sulfidic sediments (as observed here) actually enhance primary production through the dissolution of ironphosphate in the sediments, resulting in the release of pore water phosphate with the hydrogen sulfide (we cannot confirm that this was occurring here because pore water phosphate was not determined). For the salt marsh and mid-estuary sites, we would expect to see the sediment flux of total ammonia being utilized by the phytoplankton; however, we observed organic $\mathrm{C}: \mathrm{N}$ ratios that were often higher than the Redfield ratio (Fig. 6), suggesting that the phytoplankton in the surface water was not able to utilize the total ammonia fluxing from the sediments efficiently, maybe because of the observed water column stratification. At the FLUPSY, however, pumping of bottom water over the oysters (at $1.32 \times 10^{5} \mathrm{l}$ $\mathrm{h}^{-1}$ ), likely allows for the total ammonia flux from the sediment to be circulated to the surface and potentially be utilized by the phytoplankton around the FLUPSY. The sediment-flux calculations, combined with the organic $\mathrm{C}: \mathrm{N}$ ratios, suggest that there were local effects of the FLUPSY on the marine sediments, which is consistent with mussel aquaculture practices (i.e. long-line systems; Richard et al. 2007, Nizzoli et al. 2011).
The flux of hydrogen sulfide is of great concern to aquaculturists because it can be toxic to marine organisms (including those being cultivated) and can be an indicator of negative environmental effects of the aquaculture operation. Hydrogen sulfide flux from the sediments at the FLUPSY site was within the range of fluxes reported for mussel and finfish aquaculture systems (Grant et al. 1995, Miron et al. 2005, Hargrave et al. 2008).

The sediment flux of total ammonia near the FLUPSY was 2 to 20 times lower than at mussel aquaculture sites that had fluxes as high as $1500 \mu \mathrm{mol} \mathrm{m}^{-2}$ $\mathrm{h}^{-1}$ (Grant et al. 1995, Richard et al. 2007, Nizzoli et al. 2011). This could be attributable to 2 reasons: (1) the bivalves are smaller in a FLUPSY compared to long lines and (2) the FLUPSY is circulating $1.32 \times$ $10^{5} \mathrm{l} \mathrm{h}^{-1}$ of bottom water to the surface, allowing the fecal matter that is being released by the oysters to stay in the water column longer, so it can undergo microbial degradation before settling. It is impossible with our data set to determine which of these reasons is accounting for the lower flux of total ammonia.

\section{CONCLUSION}

We set out to describe and characterize the temporal and spatial variability in the East Creek embayment containing the Aeros Cultured Oyster nursery and to identify evidence of an environmental, chemical 'footprint' of this aquaculture installation, using a fixed-station approach. Measurements considered both water-column and sediment chemistry, with a focus on macronutrients and chemical compounds associated with hypoxia to address concerns about possible, adverse environmental impacts of bivalve shellfish aquaculture (Davenport et al. 2000, Prins \& Escaravage 2005, Burkholder \& Shumway 2011). Characterization of the temporal variability of the embayment revealed conditions typical of many small, coastal embayments suitable for oyster aquaculture; therefore, these results should be widely applicable.

Our results clearly show that the net effects of the FLUPSY in the embayment on the chemistry of the water column and the sediments were minimal compared to the temporal variability of the system. Our finding of negligible or only localized effects of the East Creek FLUPSY is consistent with that for $93 \%$ of 62 other ecosystems studied (Burkholder \& Shumway 2011). Overall, the chemical ecology of East Creek was little affected by the oyster nursery, and the few effects detected were not unexpected, based upon previous literature. Within $10 \mathrm{~m}$ of the FLUPSY, a 
slightly larger signal was detected in TSM, chl a concentration, and the organic $\mathrm{C}: \mathrm{N}$ ratio relative to the rest of the embayment, indicating that phytoplankton consumption and recycling of nutrients by the oysters may be occurring in the vicinity of the FLUPSY. Net inputs of total ammonia and nitrate+nitrite from the FLUPSY (Table 2) were most likely being utilized by marine phytoplankton near the FLUPSY, resulting in the larger signals at this station. This indicates that waste byproducts from the FLUPSY remain very localized, and intense recycling of nitrogen may have helped sustain primary production in the immediate vicinity of the FLUPSY.

Acknowledgements. We thank B. Blass for helping with the permitting process, and J. Alix, A. Croxton, K. Dickinson, S. M. Fuentes, A. King, C. Krome, A. Le Long, J. Rose, B. Smith and M. de Solminihac for helping in collecting estuarine transect and estuarine sediment samples. Special thanks go to D. MacDonald and D. Chu for helping obtain the microelectrode hydrogen sulfide measurements. We are especially grateful to J. Divan for providing the vessel used for sampling and for his expert piloting in holding the vessel on-station while we sampled.

\section{LITERATURE CITED}

Asmus RM, Asmus H (1991) Mussel beds: limiting or promoting phytoplankton? J Exp Mar Biol Ecol 148:215-232

Bailey EM (2005) Measurements of nutrient and oxygen fluxes in estuarine and coastal marine sediments: literature report and data review. Ref. No. UMCES CBL 05091. University of Maryland, Solomons, MD

Batley GE, Simpson SL (2009) Development of guidelines for ammonia in estuarine and marine waters. Mar Pollut Bull $58: 1472-1476$

Bayne BL, Hawkins AJS (1992) Ecological and physiological aspects of herbivory in benthic suspension-feeding molluscs. In: John DM, Hawkins SJ, Price JH (eds) Plant-animal interactions in the marine benthos. Spec Vol 46. Clarendon Press, Oxford, p 265-288

Bayne BL, Thompson RJ, Widdows J (1976) Physiology II. In: Bayne BL (ed) Marine mussels, their ecology and physiology. Cambridge University Press, New York, NY, p 207-260

Berner RA (1980) Early diagenesis: a theoretical approach. Princeton University Press, Princeton, NJ

Brendel PJ, Luther GW III (1995) Development of a gold amalgam voltammetric microelectrode for the determination of dissolved $\mathrm{Fe}, \mathrm{Mn}, \mathrm{O}_{2}, \mathrm{~S}(-\mathrm{II})$ in porewaters of marine and freshwater sediments. Environ Sci Technol 29:751-761

Burkholder JM, Shumway SE (2011) Bivalve shellfish aquaculture and eutrophication. In: Shumway SE (ed) Shellfish aquaculture and the environment. John Wiley \& Sons, West Sussex, p 155-216

Chen H, Yu Z, Yao Q, Mi T, Liu P (2010) Nutrient concentrations and fluxes in the Changjing Estuary during summer. Acta Oceanol Sin 29:107-119

Cline JD (1969) Spectrophotometric determination of hydrogen sulfide in natural waters. Limnol Oceanogr 14:
$454-458$

Cloern JE (1982) Does the benthos control phytoplankton biomass in the South San Francisco Bay? Mar Ecol Prog Ser 9:191-202

Cranford PJ, Strain PM, Dowd M, Hargrave BT, Grant J, Archambault MC (2007) Influences of mussel aquaculture on nitrogen dynamics in a nutrient enriched coastal embayment. Mar Ecol Prog Ser 347:61-78

Cranford PJ, Li W, Strand Ø, Strohmeier T (2008) Phytoplankton depletion by mussel aquaculture: high resolution mapping, ecosystem modeling and potential indicators of ecological carrying capacity. ICES CM2008/H:12, International Council for the Exploration of the Sea, Copenhagen

Cranford PJ, Hargrave BT, Doucette LI (2009) Benthic organic enrichment from suspended mussel (Mytilus edulis) culture in Prince Edward Island, Canada. Aquaculture 292:189-196

> Cutter GA, San Diego-McGlone MLC (1990) Temporal variability of selenium fluxes in San Francisco Bay. Sci Total Environ 97-98:235-250

> Davenport J, Smith RJJW, Packer M (2000) Mussels Mytilus edulis: significant consumers and destroyers of mesozooplankton. Mar Ecol Prog Ser 198:131-137

Davies JL (1964) A morphogenic approach to world shorelines. Z Geomorphol 8:127-142

Doering PH, Oviatt CA (1986) Application of filtration rate models to field populations of bivalves: an assessment using experimental mesocosms. Mar Ecol Prog Ser 31: 265-275

> Dumbauld BR, Ruesink JL, Rumrill SS (2009) The ecological role of bivalve shellfish aquaculture in the estuarine environment: a review with application to oyster and clam culture in West Coast (USA) estuaries. Aquaculture 290:196-223

Emerson S, Jahnke R, Heggie D (1984) Sediment-water exchange in shallow water estuarine sediments. J Mar Res 42:709-730

FAO (Food and Agriculture Organization) (2010) The state of world fisheries and aquaculture 2010. FAO, Rome

Folke C, Kautsky N (1992) Aquaculture with its environment: prospects for sustainability. Ocean Coast Manag $17: 5-24$

Grant J, Hatcher A, Scott DB, Pocklington P, Schafer CT, Winters GV (1995) A multidisciplinary approach to evaluating impacts of shellfish aquaculture on benthic communities. Estuaries 18:124-144

Haamer J (1996) Improving water quality in a eutrophied fjord system with mussel farming. Ambio 25:356-362

- Hammond DE, Fuller C, Harmon D, Hartman B and others (1985) Benthic fluxes in San Francisco Bay. Hydrobiologia 129:69-90

Hansen H, Koroleff F (1999) Determination of nutrients. In: Grasshoff K, Kremling K Ehrhardt M (eds) Methods of seawater analysis. Wiley-VCH, Weinheim, p 159-228

> Hargrave BT (2010) Empirical relationships describing benthic impacts of salmon aquaculture. Aquacult Environ Interact 1:33-46

> Hargrave BT, Doucette LI, Cranford PJ, Law BA, Milligan TG (2008) Influence of mussel aquaculture on sediment organic enrichment in a nutrient-rich coastal embayment. Mar Ecol Prog Ser 365:137-149

Hayes MO (1975) Morphology of sand accumulations in estuaries. In: Cronin LE (ed) Estuarine Research, Vol 2: Geology and engineering. Academic Press, New York, NY, p 157-190

> Jensen MH, Lomstein E, Sørensen J (1990) Benthic $\mathrm{NH}_{4}^{+}$ and $\mathrm{NO}_{3}{ }^{-}$flux following sedimentation of a spring phyto- 
plankton bloom in Aarhus Bight, Denmark. Mar Ecol Prog Ser 61:87-96

Jørgensen BB, Parkes RJ (2010) Role of sulfate reduction and methane production by organic carbon degradation in eutrophic fjord sediments (Limfjorden, Denmark). Limnol Oceanogr 55:1338-1352

- Kaspar HF, Gillespie P, Boyet LF, Mackenzie AL (1985) Effects of mussel aquaculture on the nitrogen cycle of benthic communities in Kenepuru Sound, Marlborough Sound, New Zealand. Mar Biol 85:127-136

Kemp WM, Sampu P, Caffrey J, Mayer M, Henriksen K, Boynton WR (1990) Ammonium recycling versus denitrification in Chesapeake Bay sediments. Limnol Oceanogr 35:1545-1563

Kemp PF, Sherr BF, Sheer EB, Cole JJ (eds) (1993) Handbook of methods in aquatic microbial ecology. CRC Press, Boca Raton, FL

Li Y, Veilleux DJ, Wikfors GH (2009) Particle removal by Northern bay scallops Argopecten irradians irradians in a semi-natural setting: application of a flow-cytometric technique. Aquaculture 296:237-245

Lin P, Chen M, Guo L (2012) Speciation and transformation of phosphorus and its mixing behavior in the Bay of St. Louis estuary in the northern Gulf of Mexico. Geochim Cosmochim Acta 87:283-298

> Loder TC, Reichard RP (1981) The dynamics of conservative mixing in estuaries. Estuar Coast 4:64-69

Maie N, Boyer JN, Yang C, Jaffé R (2006) Spatial, geomorphological, and seasonal variability of CDOM in estuaries of the Florida Coastal Everglades. Hydrobiologia 569:135-150

McKindsey CW, Archambault P, Callier MD, Olivier F (2011) Influence of suspended and off-bottom mussel culture on the sea bottom and benthic habitats: a review. Can J Zool 89:622-646

Meeuwig JJ, Rasmussen JB, Peters RH (1998) Turbid waters and clarifying mussels: their moderation of empirical chl: nutrient relations in estuaries in Prince Edward Island, Canada. Mar Ecol Prog Ser 171:139-150

Miron G, Landry T, Archambault P, Frenette B (2005) Effects of mussel culture husbandry practices on various benthic characteristics. Aquaculture 250:138-154

Newell RIE (2004) Ecosystem influences of natural and cultivated populations of suspension-feeding bivalve molluscs: a review. J Shellfish Res 23:51-61

> Newell RIE, Cornwell JC, Owens MS (2002) Influence of simulated bivalve biodepostion and microphytobenthos on sediment nitrogen dynamics: a laboratory study. Limnol Oceanogr 47:1367-1379

Nixon SW (1981) Remineralization and nutrient cycling in coastal marine ecosystems. In: Neilson BJ, Cronin LE (eds) Estuaries and nutrients. Humana, New York, NY, p 1-27

Nixon SW, Pilson MEQ (1983) Nitrogen in estuarine and coastal marine ecosystems. In: Carpenter EJ, Capone DB (eds) Nitrogen in the marine environment. Academic Press, New York, NY, p 565-590

> Nizzoli D, Welsh DT, Fano EA, Viaroli P (2006) Impact of clam and mussel farming on benthic metabolism and nitrogen cycling, with emphasis on nitrate reduction pathways. Mar Ecol Prog Ser 315:151-165

> Nizzoli D, Welsh DT, Viaroli P (2011) Seasonal nitrogen and phosphorus dynamics during benthic suspended mussel cultivation. Mar Pollut Bull 62:1276-1287

Officer CB, Smayda TJ, Mann R (1982) Benthic filter feeding: a natural eutrophication control. Mar Ecol Prog Ser 9:203-210

Prins TC, Escaravage V (2005) Can bivalve suspension- feeders affect pelagic food web structure? In: Dame RF, Olenin S (eds) The comparative roles of suspensionfeeders in ecosystems. Springer, Dordrecht, p 31-51

Prins TC, Escaravage V, Smaal AC, Peters JCH (1995) Nutrient cycling and phytoplankton dynamics in relation to mussel grazing in a mesocosm experiment. Ophelia 41: 289-315

Rice MA (1999) Uptake of dissolved free amino acids by northern quahogs, Mercenaria mercenaria and its relative importance to organic nitrogen deposition in Narragansett Bay, Rhode Island. J Shellfish Res 18:547-553

Richard M, Archambault P, Thouzeau G, Desrosiers G (2007) Summer influences of 1 and $2 \mathrm{yr}$ old mussel cultures on benthic fluxes in Grande-Entrée lagoon, îlesde-la-Madeleine (Québec, Canada). Mar Ecol Prog Ser 338:131-143

Rivara G, Tetrault K, Patricio RM (2002) A low cost floating upweller shellfish nursery system: construction and operations guide. Cornell Cooperative Extension, Suffolk, NY

> Rodhouse PG, Roden CM (1987) Carbon budget for a coastal inlet in relation to intensive cultivation of suspensionfeeding bivalve molluscs. Mar Ecol Prog Ser 36:225-236

Rozan TF, Taillefert M, Trouwborst RE, Glazer BT and others (2002) Iron, sulfur and phosphorus cycling in the sediments of a shallow coastal bay: implications for sediment nutrient release and benthic macroalgal blooms. Limnol Oceanogr 47:1346-1354

Seitzinger S (1988) Denitrification in freshwater and coastal marine ecosystems: ecological and geochemical significance. Limnol Oceanogr 33:702-724

Shumway SE (ed) (2011) Aquaculture and the environment. Wiley Blackwell, Chichester

Soto D, Mena GP (1999) Filter feeding by the freshwater mussel Diplodon chilensis as a biocontrol of salmon farming eutrophication. Aquaculture 171:65-81

Sundby B, Gobeil C, Silverberg N, Mucci A (1992) The phosphorous cycle in coastal marine sediments. Limnol Oceanogr 37:1129-1145

Swanberg Lindström I (1991) The influence of the filterfeeding bivalve Cerastoderma edule L. on microphytobenthos: a laboratory study. J Exp Mar Biol Ecol 151: 93-111

Ullman WJ, Aller RC (1982) Diffusion coefficients in nearshore marine sediments. Limnol Oceanogr 27:552-556

USEPA (1989) Ambient water quality criteria for ammonia (saltwater). EPA 882-R-99-014. US Environmental Protection Agency, Office of Water, Washington, DC

> Valdemarsen T, Kristensen E, Holmer M (2010) Sulfur, carbon, and nitrogen cycling in faunated marine sediments impacted by repeated organic enrichment. Mar Ecol Prog Ser 400:37-53

> Wallmann K, Aloisi G, Haeckel M, Obzhirov A, Pavlova G, Tishchenko P (2006) Kinetics of organic matter degradation, microbial methane generation, and gas hydrate formation in anoxic marine sediments. Geochim Cosmochim Acta 70:3905-3927

Westrich JT, Berner RA (1984) The role of sedimentary organic matter in bacterial sulfate reduction: the $G$ model tested. Limnol Oceanogr 29:236-249

Wikfors, GH (2011) Trophic interactions between phytoplankton and bivalve aquaculture. In: Shumway SE (ed) Shellfish aquaculture and the environment. John Wiley \& Sons, West Sussex, p 125-134

Wu L, Long TY, Cooper WJ (2012) Simulation of spatial and temporal distribution on dissolved non-point source nitrogen and phosphorus load in Jialing River Watershed, China. Environ Earth Sci 65:1795-1806 